\title{
Impact of Social Assistance Training on the Improvement of Performance of Labor Social Community at Balai Besar Pendidikan dan Pelatihan Kesejahteraan Sosial Bandung, Indonesia
}

\author{
Gallex Simbolon ${ }^{1, *}$, Yusuf Bayu Melani ${ }^{2}$ \\ ${ }^{1}$ Department of Non Formal Education, Graduate Program, Universitas Pendidikan Indonesia, Bandung, Indonesia \\ ${ }^{2}$ Department of Curriculum Development, Graduate Program, Universitas Pendidikan Indonesia, Bandung, Indonesia \\ *Email: gallexsl@yahoo.co.id
}

\begin{abstract}
This study was to determine the impact of training on the quality of the work social assistance Social Workers Society (TKSM) at the Center for Social Welfare Training Centre (BBPPKS) II regional Bandung. In addition to knowing the impact also to know the process of implementation of the training program of social assistance from the planning stage, holding up this evaluation. This Research using descriptive research method used is the method mix (Mixed Methods) qualitative and quantitative inductive approach is to collect data in the field through questionnaires, interviews, documents and literature. Based on the description of the results of the research show that (1) Implementation of training in Bandung BBPPKS done by needs identification of the participants; (2) training social assistance impact on the quality of work of Social Workers Society (TKSM) shown by indicators such as: performance, motivation, productivity and competence of $81.53 \%$; (3) Factors supporting the implementation of the social assistance training of internal factors namely inadequate infrastructure, insufficient funding and early identification before training. The conclusion from this study is the training of social assistance impact on improving the quality of work of Social Workers Society (TKSM) based on indicators of performance, motivation, productivity and competence can also be concluded that the initial planning process is very necessary training is designed appropriately by taking into account various supporting factors and factors inhibiting the implementation of a training program.

Keywords: impact training, performance improvement, society of social workers
\end{abstract}

\section{INTRODUCTION}

The success of development and social welfare services is influenced by the quality of social welfare workers who master the disciplines of social work. Similarly, the success of social welfare services for the social welfare of society, is determined by understanding the officer/ social worker on the development and problems faced by the community. Social work is a profession that has many dimensions, for handling various problems faced by humans and perform various activities of social change, in addition to dealing with various aspects of life and a diverse population that addressed included the main aspects of the social community [1].

Social work practice for social assistance is one of the main disciplines of social work, where the main activities include providing social assistance and the process of social empowerment through community development that emphasizes local knowledge to succeed Towards Integrated Social Welfare Development District/City Welfare. To achieve these conditions, it takes personnel who have the competencies to support the implementation of the tasks in question. But the empirical condition at this time indicates that social welfare workers in this case social assistance social welfare workers still need the knowledge, skills, and values that support the execution of their duties [2].

Most of the elements that prepare the Social Welfare Workers, social welfare development of Education and Training Center for Social Welfare (BBPPKS) Region II Bandung participate and contribute to the social assistance to people in the working area through the Implementation of the Social Assistance Training. Related to the role and responsibility of the community in the implementation of social assistance, then by decree power budget users BBPPKS Region II Bandung No. SP-DIPA 027.11.2.369084 / 2014 dated December 5, 2013, training was held on 17 and 22 November 2014 
such as "First, changes in the standard of living which is

at Balai Besar Pendidikan dan Pelatihan Kesejahteraan Sosial (BBPPKS).

Social facilitation training conducted BBPPKS Region II Bandung carried out in accordance with the training needs starting from identification of the need to evaluate the training. As an institution that aims to improve the quality of the trainees, the training model used appropriately targeted trainees are using andragogy approach (adult learning). In addition to lectures, the method used is shaped like a roll play, brainstorming, focus group discussions, social mapping and interactive dialogue. In evaluating trainees using pre-test and posttest to see an increase in knowledge, skills and attitudes of trainees.

\section{LITERATURE REVIEW}

\subsection{Concept of Non Formal Education}

According to Sudjana[3] gives the sense of Non Formal Education as following: "Non Formal Education is any organized educational activity outside the school system implemented individually or an important part of a comprehensive activity, with the purpose of providing services, especially on the learners in achieving learning goals".

According to Philips H Combs[4] revealed that the Non Formal Education are as follows:"Every educational activities organized and held outside the formal system either alone or as part of an activity that is widespread, with the purpose to provide services to specific target students in order to achieve the objectives of learning".

\subsection{Training Concept}

According Sikula[5] argues that, training is short-term educational process that uses systematic and organized procedures. The definition illustrates that training is an activity that is designed to describe resources through a series of activities of identification, assessment and learning processes planned. This is done through efforts to help develop key skills required in order to carry out the work, both now and in the future.

The purpose of the training is to prepare someone to carry out the work satisfactorily or prepare someone to bear a heavier responsibility in the present and in the future.

\subsection{Effect}

Influence or impact is positive or negative effect of an activity carried out. Sudjana[3] states that the influence regarding the results achieved by learners and graduates, marked by the acquisition of work or entrepreneurship, acquisition or improvement of income, health, and selfappearance. Second activities involve another person in utilizing learning outcomes that have been held. Thirdly, the increased participation of ideas, energy, property and funds ".

\subsection{Community Social Workers}

Assistance can be understood as a community development activities by placing assistants as a facilitator, communicator, motivator and a dynamic. In essence, mentoring is an effort to include the community in developing a wide range of potential so as to achieve a better quality of life. Moreover directed to facilitate the decision-making process related to the needs of the community, to build capability in raising revenue, implementing large-scale business enterprises as well as develop the planning and implementation of participatory activities.

Basically assistance program (assistants) have three basic roles include: (1) Advisory Group. Companion role to give advice and consideration required by the group in the face of problems. Companion not decide what needs to be done, but the group that will make the decision; (2) Trainer Participatoris. The companion has a role providing various basic capabilities required by such groups manage meetings, bookkeeping, administration, solve problems, make decisions and so on; (3) Link Person. Companion role as community liaison with relevant agencies (stakeholders) and necessary for the development of the group [6].

\subsection{Factors Affecting the Quality of Work Employees}

Organizations tend to work best characterized the organization of open, teamwork, challenging jobs, as well as fair and equitable treatment in other words, is characterized by the presence of a high-quality working life. According to Dessler[7] quality can reach employee if the employee can meet their important needs can work within the organization, and the ability to do so is affected or depend on whether there are any: (1) The treatment is fair, equitable, and fair to the employees; (2) An opportunity for each employee to use fully ability and opportunity to realize ourselves, which is to be the one that they feel able to make it happen; (3) Open communication and mutual trust among all employees. Opportunity for all employees to actively participate in making important decisions involving their jobs; (4) Adequate and fair compensation; (5) A safe and healthy environment 
With the state of the atmosphere is so, then the work quality can be realized so as to determine the purpose of the jobs in achieving the target or not. Measurement of quality of work that could affect the jobs goal are as follows: (1) Quantity of work, can be seen from the large number of jobs generated; (2) Quality, work can be seen from the results obtained from a job that is used to improve the quality of a company; (3) Timeliness, can be seen from the percentage of employees who report on time; (4) Work discipline, activities implemented to encourage employees to follow the standards and rules, so that abuses can be prevented.

It would also require the elements that support the creation of quality improvement officer job, among others: (1) Compensation; (2) Welfare; (3) Work relationship; (4) Training for managers; (5) Opinion survey; (6) Assessment of achievement; (7) Flexible working hours; (8) Control group; (9) Fund spending.

Based on the above elements we can notice that the quality of the work programs for the most part based on techniques, such as hours of work organization level. Techniques including management by objectives, program quality groups, and new working arrangements and also enrichment work indeed play a major role in the quality of work, such techniques are elements that jointly affect the quality of work in the workplace [8].

\subsection{Indicators of Quality Work Employees}

According Mayalu Hasibuan[9], an indicator of the quality of work of employees, namely: (1) Self Potential, self-potential is the ability, the strength, both of which have not materialized and that have been realized, which is owned by someone, but not yet fully seen or used optimally. According Parlindungan[10] "The potential for self is the ability hidden in every person, every person has it". Understand the job description and have the ability to develop areas of work and have the initiative to is a few potential to be possessed employees; (2) Optimal Working Results, optimal working results must be owned by an employee, the employee must be able to give her the best results, one of which can be seen from the organization's productivity, quality of work, quantity of work. The productivity of the organization is as a measure of the use of my resources in an organization is usually expressed as the ratio of output achieved with the resources given. Quality of work is an activity performed by employees have met the various requirements, specifications and expectations that have been set. The quality of work is as good as the quality of work or what must be completed. The quality of employee can be seen from their ability to produce a satisfactory job, achievement of objectives effectively and efficiently and demonstrated proficiency in carrying out his job; (3) Working Process, the working process is an important stage in which employees perform tasks and role in an organization, through the process of this work performance of employees can be seen from the ability to plan work, creative in carrying out the work, evaluate the work action, take corrective action. Excellent performance and quality can be seen from how an employee can do a job, from planning to the improvement. Employees who have a work plan that mature, high creativity, able to evaluate the action, and can, improve the action without waiting for orders from superiors is an employee who has a rational thought and initiative alone for do the job. As expressed by Malay SP Hasibuan[11] argues that: With the initiative of employees in the implementation of the work process in designing the work program, and be able to solve the problems faced, then organisation will succeed in achieving the goals set. Thus in order to achieve the objectives to be achieved within the organization, then the employee must have the ability in the execution of the work process job; (4) Antusiasme, Enthusiasm is an attitude where an employee doing his job this concern can be seen from the presence, execution of tasks, work motivation, job commitment. Employees who have the enthusiasm will continue to improve its performance in carrying out all the duties and responsibilities it should always be grown in the soul of employees in an effort to improve the quality of its performance. DA Soetisna[12] argues that: The spirit or enthusiasm is an attitude of employees in carrying out its work, which has the capacity to actively work tirelessly. This is a tendency to use positive behavior, emotions, and spirit.

\section{METHOD}

The method used in this research is descriptive method, which is a research method that is intended to describe the phenomena that exist, which has lasted or past. Nazir[13] states that literally, descriptive method is a method of research that makes a picture of the situation or event, so this method intends to hold periodic accumulation of basic data. The purpose of descriptive research is to create a description, picture or painting in a systematic, factual and accurate information on the facts, nature, and the relationship between the phenomena under investigation.

Researchers chose to use descriptive method aims to describe or depict the impact of the Social Assistance Training is already underway in Bandung BBPPKS TKSM to the improved performance.

The collected data is classified into two groups, namely the data, qualitative and quantitative data. Data were 
prefer to use certain motivation. A participant has a strong presence in the group of non-formal education when showing behavior in a way which supports and develops his/her own importance and the importance of the other participants. Here comes a short description of different motivation styles which can help us diagnose better the participants' behavior.

\subsection{Discussion}

Non Formal Education as training providers are expected to perform a variety of new findings for training progress. Each training undertaken expected to deliver maximum results to all participants not just routine. How new concepts applied and the real breakthrough that school education to become a professional art education including training in the study [14].

Thus the non-formal education becomes more and more full fledged process of learning and training based on sound principles, more and more structured, requiring the preparation on behalf of the educators and trainers. Non-formal education is becoming not only legitimate part of the education nowadays but as well is a more and more codified field where the role of the educator is well defined and where systems for pre-service and in-service training are elaborated.

In the basis of work in the Non-formal education group is structured activities or exercises. These activities and exercises model reality, present its important elements, provide a possibility for its exploration and usually includes the participants experience (implicitly or explicitly). Exercises enrich the existing experience with new things and require sharing and recycling of the received information. This way we reach the paradox of group work - small structure units (exercises) are in the basis of its dynamics. Participants' personality, their perceptions, emotions, thoughts are fully involved by the exercises. Through the exercises they connect to the other participants in a meaningful way, in and through them they are equal - gain experience, have mutual basis for communication thanks to the experiences and are also equal in the process of discussion because they have gone through the same thing (although in different ways). Not less important is the meaning of the exercise as a possibility to try out skills and behavior, to check hypothesis as its structure creates safe conditions for such actions.

According to new theories with elements of sharing, their stimulating character and the relatively safe environment where they are held as well as in many cases the fact that they are new, exercises develop participants' mind and a basis for personal and professional development. 
less perceived training useful for performance and countless wasted because it can not apply the knowledge

\section{CONCLUSION}

In the context of education as an effort to educate the public and increase the potential of the nation, Non formal education is not a supplement, complement, or substitute for non formal education. Non Formal Education and formal education engaged in a parallel position. Another thing that is very important to be taken into consideration that the non formal education as a solution to community empowerment Indonesia during the present crisis, namely; that the non formal education is seen as a practical and contextual education, programs can be organized according to the type, quality, and the level of the real needs of the learners (learners) as well as the environment that just immediately or in the long term. Non formal education theory disclosed of proven field experience and do not rotate on their own circles (inner gyroscopic), but lead, accompany, or immediately following the dynamics of the community.

Training institutions as one of the non-formal institutions is a study of school education should be able to form a good concept and provide benefits to the trainees. So the implementation of a training routine not only in completing the work program of the government. Similarly, the training held in BPPKS based research found that training had a positive impact for the trainees who then fell into the community to deliver the knowledge they gained during the training. Factors supporting the implementation of the training of social assistance from internal factors namely: training programs according to the needs of participants because it begins with the initial identification before training, there are adequate funds, facilities and infrastructure support, post-training knowledge gained can be directly applied on the job every day. In addition there are also external factors, namely: training participants were enthusiastic about the training, the participant's home Institutions that support participants to attend the training, trainees follow all rules set proved from all the participants who took part in accordance with the requirements, and the agency is very helpful in the evaluation process, evidenced so easily obtain data alumni, Come support the training and socialization program Partners program providers also strongly supports the full implementation of the training, evidenced by helping provide trainees, helping to provide educators or speakers

Internal factors inhibiting training of social assistance are: speakers sometimes not timely when it will provide the material. There was also an inhibiting factor that comes from the outside (external) such as: Delivery of training information that is organized is sometimes hampered by inadequate communication tools, particularly in the area of rural communities, and also the rapid turnover of employees in the area, resulting in did got.

\section{REFERENCES}

[1] N. Husna, "Ilmu Kesejahteraan Sosial dan Pekerjaan Sosial,” J. Al-Bayan, vol. 20, no. 29, pp. 45-58, 2014.

[2] M. J. Maspaitella and N. Rakahbuwi, "Social Welfare Development : Society Empowerment in Social Worker Approach Nancy Rahakbauwi," Aspirasi, vol. 5, no. 2, pp. 157-164, 2014.

[3] D. Sudjana, Pendidikan Non Formal. Bandung: Falah Production, 2004.

[4] M. M. Ulum, "Menakar Jalur Pendidikan Luar Sekolah: Memunculkan Asa di Era Otonomi Daerah," Cendekia, vol. 9, no. 2, pp. 169-176, 2011.

[5] S. Sumantri, Pelatihan dan Pengembangan Sumberdaya Manusia. Bandung: Fakultas Psikologi UNPAD, 2001.

[6] M. A. Kurniawan, "The Role of Social Workers in the Empowerment and Social Protection of Client in LK3 (Family Welfare Consultancy) 'Teratai' Yogyakarta," Diklus J. Pendidik. Luar Sekol., vol. 2, no. 1, pp. 45-52, 2018.

[7] G. Dessler, Manajemen Sumber Daya Manusia. Jakarta: Prenhallindo, 1997.

[8] N. M. R. Amalia and S. Indartono, "The Effect of Work Environment and Motivatiion on the Employee Performance in Dinas Tenaga Kerja and Sosial Kabupaten Sleman,” J. Fak. Ekon. Tahun, pp. 622-634, 2018.

[9] H. S. Utomo and M. Nugroho, "Model Peningkatan Kinerja Karyawan melalui Kualitas Kehidupan Kerja,” Ekobis, vol. 15, no. 1, pp. 31-50, 2014.

[10] E. Safitri, “Optimalisasi Pemanfaatan Potensi Lokal dalam Pemberdayaan Ekonomi Masyarakat di Desa Sukamulya Kecamatan Banyumas Kabupaten Pringsewu," Universitas Islam Negeri Raden Intan Lampung, 2018.

[11] N. Khurotin and T. W. Afrianty, "Analisis Pelatihan dan Pengembangan Sumber Daya Manusia di PT Beon Intermedia Cabang Malang," J. Adm. Bisnis, vol. 64, no. 1, pp. 195-203, 2018.

[12] R. Attamimi and G. M. Pentury, "Pentingnya Sikap Positif untuk Menjamin Proses Kepemimpinan, dan Peningkatan Kinreja (Studi pada Perusahaan Manufaktur di Surabaya)," Soso-Q, vol. 3, no. 2, pp. 88-101, 2010.

[13] M. Nazir, Metode Penelitian. Jakarta: Ghalia Indonesia, 2003. 
[14] Y. K. Efendi, "Pelaksanaan Program Pendidikan Pelatihan di Dinas Tenaga Kerja Transmigrasi dan Kependudukan Pemerintah Proopinsi Jawa Timur," Khazanah Pendidik., vol. X, no. 2, 2017. 